\title{
Russia to boost university science
}

\section{But can it break the dominance of the Russian Academy of Sciences without breaking the research base?}

Technological leadership, a matter of national pride during the Soviet glory days, has become a distant memory in modern Russia, where scientific output lags behind that of China, India and South Korea. Despite increased funding in recent years, Russian science has not yet recovered from a near collapse in the 1990s and the consequent exodus of thousands of researchers to the West.

In an attempt to counter the decline and to foster science-driven innovation, the Russian government is betting on its universities, by promising to invest an extra 90 billion roubles (US $\$ 3$ billion) into higher education and mar-

\begin{tabular}{|c|c|c|c|c|}
\hline \multicolumn{5}{|c|}{ SIZE ISN'T EVERYTHING } \\
\hline & $\begin{array}{l}\text { Russian } \\
\text { Academy } \\
\text { of Sciences }\end{array}$ & $\begin{array}{l}\text { Chinese } \\
\text { Academy of } \\
\text { Sciences }\end{array}$ & $\begin{array}{l}\text { Max Planck } \\
\text { Society } \\
\text { (Germany) }\end{array}$ & $\begin{array}{l}\text { National Centre for } \\
\text { Scientific Research } \\
\text { (CNRS, France) }\end{array}$ \\
\hline Number of researchers & 56,760 & 39,000 & 4,700 & 11,600 \\
\hline $\begin{array}{l}\text { Number of publications on } \\
\text { Scopus* }\end{array}$ & 81,075 & 109,727 & 43,109 & 117,311 \\
\hline $\begin{array}{l}\text { Average number of publications } \\
\text { per researcher }{ }^{\star}\end{array}$ & 1.43 & 2.81 & 9.17 & 10.11 \\
\hline $\begin{array}{l}\text { Average number of citations of } \\
\text { each publication* }\end{array}$ & 2.66 & 3.8 & 11.97 & 7.42 \\
\hline
\end{tabular}
ket-oriented university research over the next decade, on top of an annual university research budget of about 20 billion roubles. But doubts remain about whether the initiatives can overcome weaknesses in the universities and the long-standing dominance of the Russian Academy of Sciences (RAS), the largest basic research organization in the country. The RAS, which employs more than 50,000 researchers in 480 institutes across the country (see 'Size isn't everything'), gets about 50 billion roubles per year in funding from the federal government. Yet it suffers from an ageing scientific workforce and poor links with the international scientific community.

As Russia struggles to overcome its economic dependence on mineral exports, academy researchers are criticized for contributing too little to Russia's transformation into a high-tech economy. "Increasing domes-

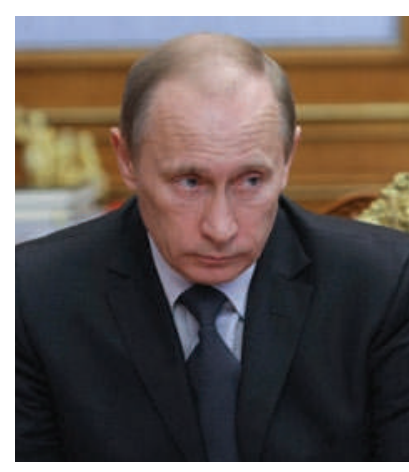

Vladimir Putin wants universities to produce more science-based innovation. from regional governments, these institutions will each receive an extra 1.8 billion roubles per year over the next decade from federal budgets for purchasing modern laboratory equipment. Twelve winners were selected last year, and a further dozen or so will be chosen this month out of 128 institutions that applied in the second round of the competition.

Last year, the government also created five 'federal universities' to bolster higher-education efforts in under-resourced areas; they will each receive around 380 million roubles annually in extra funding over the next three years.

Separate budget lines were also set aside to support Moscow State University and St Petersburg University, the two largest and scientifically strongest institutes of higher education in the country.

Finally, Russian Prime Minister Vladimir Putin announced a new grant protic high-tech production will require a flow of well trained people to industry," says Nikolay Ledentsov, a corresponding member of the RAS formerly with the Ioffe Physico-Technical Institute in St Petersburg, who now runs the optoelectronic company VI-Systems in Berlin, Germany, which he founded in 2006. "Improving universities, where most people are educated, makes sense."

To strengthen neglected university research - mainly in applied sciences such as information technology - the government launched a competition in 2008 to transform a number of existing institutions into 'national research universities'. On top of their regular funding gramme earlier this month worth a total of 12 billion roubles. It is aimed at attracting highprofile scientists from within the country and abroad to work at Russian universities. Winners, chosen for their research and publication record, will receive up to US $\$ 1$ million per year to set up a team at a Russian university of their choice. A first call for proposals is being prepared, and the first grantees are to be selected later this year.

Hopes of creating a Russian match for Harvard or Oxford, voiced by some institutions bidding to become national research universities, are wildly premature, says Konstantin Severinov, a biochemist based at both Rutgers University in New Brunswick, New Jersey, and at the RAS Institute of Molecular Genetics in Moscow. He and others warn that the new funding is still being funnelled through a system that often fails to reward the best ideas, and lacks the transparent grant-assessment procedures developed and accepted by the international scientific community.

Still, Severinov says, promoting university research is certainly a welcome step towards breaking the unhealthy dominance of the RAS in favour of a more diverse science and highereducation system. "Merging science and higher education is the right approach," he says. "If the new initiatives help get more Russian students involved in meaningful research early on it would be a good thing."

Some researchers worry that boosting the universities could damage the RAS. "It's in everybody's interest to have strong universities, but please not at the expense of damaging the RAS where the best science is done," says Ledentsov. The best way to revitalize Russian science is to let both universities and RAS institutes to compete for public funding through a quality-based granting system, he says. "Russian science needs a fruitful combination of both, and it absolutely needs stronger links with Europe."

Increased funding is only part of the remedy, adds Ledentsov. Russian government initiatives include a 318-billion-rouble nanotechnology programme started in 2007 (see Nature 461, 1036-1037; 2009) and plans for a new science city outside Moscow. But these must be supported by innovation-friendly business and legal reforms such as tax exemptions for company research and development.

"You can't order innovation," says Ledentsov. "But you can force the economy to be innovative if you create the right incentives. Seed it and it will grow."

Quirin Schiermeier 